\title{
Corporate Ownership, Internet Penetration and Internet Financial Reporting: Evidence from the Gulf Cooperation Council Countries
}

\author{
Akmalia M. Ariff*, Hasan O. Bin-Ghanem and Hafiza Aishah Hashim
}

\begin{abstract}
Manuscript type: Research paper.

Research aims: This study aims to examine how the individual effect of company-level ownership structure and the joint-effect of company-level ownership structure with country-level Internet penetration, can impact on Internet Financial Reporting (IFR).

Design/ Methodology/ Approach: An index consisting of 35 IFR items was used to collect information from 152 listed financial companies from the Gulf Cooperation Council (GCC) countries. These companies were from Bahrain, Oman, Qatar, Saudi Arabia and the United Arab Emirates. Data were analysed using regression analysis. Research findings: The findings imply that companies with high government and family ownerships have lower extent of IFR. High quality IFR is evident in companies located in countries with a strong Internet penetration. However, the association between corporate ownership structure and IFR is not influenced by the country's Internet penetration.

Theoretical contributions/ Originality: Our study is the first crosscountry comparative analysis that utilises data from the GCC countries to explore the determinants of the IFR. This study incorporates
\end{abstract}

\footnotetext{
* Corresponding author: Akmalia M. Ariff is a Lecturer at the School of Maritime Business and Management, Universiti Malaysia Terengganu, 21030 Kuala Nerus, Terengganu, Malaysia. Email: akmalia.ariff@umt.edu.my

Hasan O. Bin-Ghanem is a Lecturer at the Faculty of Administrative Sciences, Hadhramout University of Science and Technology, Hadhramout, Yemen. Email: binghanem_h@hu.edu.ye Hafiza Aishah Hashim is a Lecturer at the School of Maritime Business and Management, Universiti Malaysia Terengganu, 21030 Kuala Nerus, Terengganu, Malaysia. Email: hafizaaishah@umt.edu.my
} 
company-level governance and country-level institutional factors which are relevant and unique in the context of the GCC to add to the existing evidence that had mainly concentrated on a single-country setting or the developed market.

Practitioner/ Policy implications: The findings of this study, which are related to the negative impact of government and family ownership on IFR can be attributed to the regulators in the GCC countries. It is recommended that the GCC improve its enforcement of legal protection for shareholders so as to protect the minority shareholders' interests.

Research limitation: Future cross-country analysis on IFR can focus on other emerging markets that differ from the GCC. In addition, these studies can consider other relevant company-level governance aspects such as managerial ownership and country-level institutional factors such as cyber security risks as variables.

Keywords: Ownership, Internet Penetration, Gulf Cooperation Council.

JEL Classification: G11, G02, C91

\section{Introduction}

Internet Financial Reporting (IFR) benefits companies. It increases the companies' overall transparency and promotes the public's awareness about the performance of these companies (Kelton \& Yang, 2008). At the same time, it reduces information asymmetry (Puspitaningrum \& Atmini, 2012). Financial companies in the Gulf Cooperation Council (GCC) region are expected to expand their activities globally and to raise their capital internationally (Al-Obaidan, 2008; Aly, Simon, \& Hussainey, 2010) and without doubt, this goal can be accomplished through technology. The heightened use of the Internet can facilitate the dissemination of information to a wider circle of potential stakeholders comprising national and cross-border investors. However, since the IFR practices are generally voluntary and unregulated (Dutta \& Bose, 2007), there are variations in the manner companies implement their IFR practices. This study examines the effect ownership structure and Internet penetration of companies have on their IFR practices. The aim of this study is to test whether Internet penetration moderates the relation between ownership and IFR.

Corporate governance refers to the mechanisms, processes and relations by which companies are monitored and controlled for good 
practices. Some corporate governance mechanisms that are used to gauge a company's overall information disclosure have significant roles to play in the IFR practices policy (Kelton \& Yang, 2008). Prior studies that examined the role of corporate governance in IFR practices have tended to focus on developed countries (e.g. Kelton \& Yang, 2008; Xiao, Yang, \& Chow, 2004) or on a single-country (e.g. Elsayed, ElMasry, \& Elbeltagi, 2010). Undeniably, the findings of these empirical investigations are significant but there appears to be a lack of focus in looking at some aspects of governance that can hamper good governance and IFR in developing countries such as the GCC region.

Aiming to address this gap, the current study thus concentrated on the GCC countries. The empirical evidence drawn from the GCC market can add to the existing knowledge involving IFR studies. Our study takes into account the legal system, providers of finance, socio-economic environment and political norms of the institutional environment of these countries and we hypothesise that these will differ from those of the developed regions. We reason that these institutional factors can significantly influence the accounting systems/standards of the respective countries in the region thereby affecting the region's disclosure of financial information. In this regard, we argue that robust corporate governance plays an important role in less matured economies because its good practices can encourage foreign investments and promote economic growth.

Instead of focussing on corporate governance from the board of directors' composition and their roles (e.g. Botti, Boubaker, Hamrouni, \& Solonandrasana, 2014), our study focusses on the governance aspect which involves the composition of corporate ownership structure. This is because unlike developed markets, emerging countries face issues such as agency costs which have resulted from the conflicts that exist between controlling owners and minority shareholders and not conflicts between managers and owners (Fan \& Wong, 2002). There is evidence to show that companies in emerging markets adhere to the checklist of best practices as set by the security regulators. However, this adherence is conducted mainly for appearances and not for substance. Corporate boards are also deemed as mere rubber stamps for management decisions (Bussin, 2012) because these boards are often made up of the "old boys' clubs" whose members are so familiar with each other that they often overlook regulations. Without doubt, this phenomenon had caused the role of corporate governance to be more focused on ownership structure rather than on the composition of the boards. 
Turning our attention to the institutional context of the GCC region, this study examines the company-level governance that is related to government ownership and family ownership. Both types of ownership structures, although commonly employed and are essential in the economic development of the GCC countries (Santos, 2015; Baydoun, Maguire, Ryan, \& Willett, 2013; Maghyereh \& Awartani, 2012), may provide a source of incentives that have the propensity to generate a substantial agency problem.

By making a cross-country comparative analysis, this study is able to further explore the interplay that exists between governance and the IFR. This is achieved by considering the firm's external environment as an important factor in influencing IFR decisions (Debreceny, Gray, \& Rahman, 2002). Despite the many sociocultural and institutional similarities, the GCC countries also have disparity in terms of their respective Internet penetration rates (Alqudsi-ghabra, Al-Bannai, \& AlBahrani, 2011). Further, in the GCC countries, the interplay between significant aspects of corporate governance of companies and their institutional environment is essential. It helps to disentangle the factors that are most prevalent in determining corporate disclosure practices and transparency. Our study adds to the literature of the IFR by examining the joint effect of company-level and country-level factors on the IFR. One of the contributions drawn from our study will show that when the country's Internet penetration rate is strong, it is easier and less costly to strategically provide financial information via the Internet. This occurs despite getting no pressure from the controlling shareholders hence, it increases the quality of the IFR. However, despite the feasibility of providing company information via the Internet, there is a prevalence of a core factor which hinders the process. This can be traced to the lack of demand for IFR disclosures from the controlling shareholders hence, a low quality IFR is expected.

Our sample consists of 152 financial companies enlisted from the six countries of the GCC: Bahrain, Kuwait, Oman, Qatar, Saudi Arabia and the United Arab Emirates. The financial sector in the GCC countries is relatively developed (Khediri, Charfeddine, Youssef, 2014) due to the high economic growth that prevailed in the last two decades (Mohamed \& Basuony, 2014) and also as a result of the development of Islamic banking in the region (Gheeraert, 2014). The strength of financial companies is fundamental in establishing a sound financial system within the GCC countries. In this regard, we posit that government and family ownerships of these financial companies affect the IFR. However, 
the association between these corporate ownership structures and the IFR is influenced by the country's Internet penetration rate. We believe that our findings, which are derived from analysing the 2012 data of these GCC countries, are relevant in the current scenario. This is because the need to provide transparency in securing investments has escalated but the process is still being hampered by the embedded deficiencies of the ownership structure and the governance practices of the companies concerned.

The remainder of this paper is structured as follows. Section 2 provides the literature review and the hypotheses development. Section 3 discusses the research methodology. Section 4 presents the results and Section 5 concludes the paper.

\section{Literature Review and Hypotheses Development}

\subsection{The Role of the Financial Sector in the GCC Countries}

During the period when economic growth in the GCC countries was fuelled by booming oil revenues, the interest for investment opportunities was also developing at a rapid rate (Basuony \& Mohamed, 2014). This interest is still very prevalent today in these countries although they are experiencing a subdued GDP growth which is caused by the slide in oil prices as well as the political unrest of neighbouring countries. Under both these circumstances, companies in the GCC countries have no choice but to expand their activities globally, with the intention of raising their capital internationally. This desire has become a global objective of the GCC (Al-Obaidan, 2008; Aly et al., 2010) as is evidenced by the reforms implemented by the GCC countries. These reforms were implemented as a move towards improving their business climate and competitiveness, a move that has been approved by the World Bank (2018), as stated in its Doing Business Report 2018. There has been a mixed picture painted about foreign direct investments (FDIs) coming into the GCC countries (United Nations, 2017) but the GCC is forging ahead with their economies because it is believed that the longterm economic diversification plans can help to build their economies. To stimulate this economic growth, support has to be provided through the fiscal policies and the growth in non-hydrocarbon sectors. Some examples of this long term plans include Saudi Arabia Strategy 2025, Oman - Vision 2020, the UAE - Vision 2021, Bahrain - Vision 2030 and the Qatar National Vision 2030. 
The financial sector plays a key role in the economies of the GCC countries. This is because it serves as the financial intermediaries which support the continuing growth of the countries' oil and gas sector as well as their non-oil sectors. Analysis on the 2016 published annual earnings of 56 leading listed commercial banks across all the GCC countries stated that the overall outlook for the GCC's banking sector is positive and that the sector will remain resilient to the current economic challenges (KPMG, 2017). This outcome could be accomplished through the ongoing government support and their infrastructure investments. The financial sector is one of the most economically viable diversification option for investors. It is the second highest contributor to the country's GDP, after the oil and gas sector. It is also dominated by the banking sector which remains to be the cornerstone of the non-oil GDP growth in the economies of the GCC countries (Al-Obaidan, 2008; Al-Hassan, Oulidi, \& Khamis, 2010). Due to the growth of Islamic finance in the GCC region, as one of the world's largest Islamic banking markets, the role of the financial sector have become even more emphasised (Khediri et al., 2014).

The GCC countries' dominance in oil, gas and other natural resources makes the region similar in some ways. These countries possess specific features that differentiate them from other industrialised or developing economies. An example is their high degree of state regulation (Samargandi, Fidrmuc, \& Ghosh, 2014). There has also been extensive reforms involving the financial sectors of the GCC countries as the GCC region aims for more integration with the global community and a diversification in their economies (Kamla \& Roberts, 2010; Maghyereh \& Awartani, 2014). Some of these reforms include strengthening banking regulations and supervision, removing interest rate controls, and making moves towards open market policies. This means that the financial sectors are facing major challenges which involve dynamic shifts in regulations, demands for deregulation, globalisation and development in banking techniques and services (Chahine, 2007; Al-Obaidan, 2008). The significant structural changes involving the financial sector aim to stimulate financial liberalisation and financial restructuring which can make the banking sector more competitive (Maghyereh \& Awartani, 2012). In particular, the Islamic financial institutions face additional agency problems (Safieddine, 2009) because of the need to maximise shareholders' wealth which is in compliance with Shari'ah laws. In this regard, financial companies in the GCC region are more highly motivated in disseminating information 
which is done by engaging in Internet activities (Bollen, Hassink, \& Bozic, 2006).

\subsection{Internet Financial Reporting (IFR)}

The objective of financial reporting in the modern business environment is to assemble financial information that is useful to existing and potential investors, lenders, creditors and other users for making decisions about providing resources to a company (Al-Shammari, 2013). Rapid developments in information and communication technology have led organisations in many countries to consider the impact of the Internet on the delivery and dissemination of business information (Beattie \& Pratt, 2003; Jones \& Xiao, 2004). The developments involving the Internet have increased the demand for online corporate information, in general, and financial information, in particular (Alali \& Romero, 2012). These demands have resulted in the evolution of financial reporting, shifting from conventional means of the print-based to the modern Internet-based reporting (Al-Htaybat, 2011).

Corporate information disclosed through the Internet helps users, especially small or foreign investors who do not have direct and immediate access to the company's financial information (Trabelsi, Labelle, \& Dumontier, 2008). Likewise, the IFR is seen as a mechanism that can help to reduce information asymmetry (Healy \& Palepu, 2001; Trabelsi et al., 2008; Cormier, Ledoux, \& Magnan, 2012) and this can therefore, increase the liquidity of the firm's stocks and reduce its cost of capital (Healy \& Palepu, 2001; Botosan \& Plumlee, 2002). The IFR enables a relatively cheap and an extremely fast and great presentation of useful information in varying formats. It helps companies to disclose and share information about the companies' performances and activities through interactive and connected reports, to millions of Internet users on a daily basis (Pervan, 2006). The mechanism provides information instantaneously to a global audience (Abdelsalam, Bryant, \& Street, 2007), disclosing a more up-date information hence improving efficiency and effectiveness (Kelton \& Yang, 2008). The mechanism also encourages investment (Aly et al., 2010) and creates an overall increased market transparency and public awareness (Kelton \& Yang, 2008; Ali-Khan, Ismail, \& Zakuan, 2013). These advantages make the IFR an increasingly preferred means of corporate communication. It also helps companies to overcome issues such as significant maintenance costs, information 
overload as well as trust and security (Andrikopoulos, Merika, Triantafyllou, \& Merikas, 2013).

Despite the usefulness of the IFR, there are variations in how this is practised among countries. Many studies (Ashbaugh, Johnstone, \& Warfield, 1999; Craven \& Marston, 1999; Ghnaya, 2015) have focussed on firms' characteristics as the determinants behind the variations. Focussing on developed countries, Ashbaugh, Johnstone and Warfield (1999) examined U.S. firms while Craven and Marston (1999) studied companies in the U.K. context. Both these studies indicate that larger firms have more tendencies to utilise IFR. Studies that follow suit expanded the earlier researches by including data from developing countries such as Ghnaya (2015) and Ahmed, Bruce and Theresa (2017). Literature discussing the IFR (e.g. Ali-Khan \& Ismail, 2011; Turmin, Hamid, \& Ghazali, 2015, Qasim \& Al-Barghouthi, 2017) has introduced various theories which also disclosed the identification of various determinants of the IFR. These determinants include leverage, profitability, liquidity and types of auditors. A meta data analysis done by Mokhtar (2017) confirmed the prediction stressed by the agency theory, signalling theory, political cost hypothesis and innovation theory for explaining the IFR. Mokhtar (2017) found that other than size, there was a significant positive association between profitability, leverage, auditor type and Internet reporting. Therefore, it was recommended that studies on IFR consider these characteristics of firms as determinants for IFR practices.

Despite the growing importance of the IFR and the advantages it offers to the financial markets, the IFR is still in its infancy stage in the GCC countries (Oyelere \& Kuruppu, 2012; Basuony \& Mohamed, 2014). Many factors impede the utilisation of the Internet for financial reporting in the GCC countries and this encompass the social, cultural, institutional, and legal factors (Moradi, Salehi, \& Arianpoor, 2011). Prior studies (e.g., Al-Shammari, 2007; Basuony \& Mohamed, 2014), including those conducted in the GCC countries, indicate that the variation or differences noted in the level of IFR disclosure between these countries are expected. This is attributed to the differences in capital market development, differences in macroeconomic trends and differences in corporate governance practices and reporting (Bartulović \& Pervan, 2012; Botti et al., 2014). Evidence was traced to the Behavioural Assessment Score for Investors and Corporations (BASIC) which had observed that companies in the GCC region had received a low score on disclosure (3.24/10.0). The BASIC score that looked into 
the communication standards for disseminating important information to the stakeholders such as the availability of websites, had observed that companies in the GCC countries were still withholding important information from shareholders due to the region's renowned culture of secrecy (Halawi \& Awan, 2008). While there is an increasing need for the IFR to be implemented in the GCC region, information has not been forthcoming. The poor IFR disclosure practices may lead to losses for domestic as well as foreign shareholders.

\subsection{Corporate Governance and IFR}

Studies (e.g. Ojah \& Mokoaleli-Mokoteli, 2012; Debreceny et al., 2002; Turrent \& Ariza, 2012) linking the IFR disclosures with the dimensions of corporate governance, such as the board of directors, audit committee and ownership structure, provide evidence from the perspective of a single country or a few countries. The results gathered from these studies suggest that there is a greater demand for information to be delivered in content details and in speed among companies that practises good governance. As such, corporate governance is important in the adoption of the IFR. However, empirical evidence noting the relationship between corporate governance characteristics and IFR disclosures had been mixed and inconclusive. The mixed findings could be attributed to the different types of corporate governance mechanisms which have been applied in different institutional settings. In addressing this concern, our study explores the governance aspects from the corporate ownership structure in the GCC countries by focusing on government and family ownerships.

Contrary to a majority of companies in developed countries, corporate ownership structures in GCC countries are highly concentrated. Many GCC listed companies are mainly dominated by families (Chahine, 2007; Baydoun et al., 2013) whose members can influence the board's decision and where family members can be appointed onto the corporate board. GCC listed companies can also be dominated by the government (Maghyereh \& Awartani, 2012). As can be noted, governments and quasi-government agencies take charge of funds such as pension and sovereign funds. These agencies own a substantial amount of securities (Al-Khouri, 2012). Such concentrated ownerships could adversely affect the rights of minority shareholders (Baydoun et al., 2013) and this is an indication of the high information asymmetry 
(Orens, Aerts, \& Cormier, 2010). In this regard, the demand for IFR is expected to vary as a result of these dominant ownerships, based on the variations in agency conflicts and information asymmetry. Therefore, it is unclear whether the GCC companies, which explicitly suffer from high ownership concentrations, have the tendency to improve their IFR so as to protect the rights of minority shareholders.

\subsubsection{Government Ownership and IFR}

Theoretically, there are two opposite perspectives on how government ownerships affect voluntary disclosure. Firstly, according to the agency theory, government ownership increases moral hazards and agency problems. Wang (2003) argued that government shareholders have a higher degree of political influence due to its status of being purely government agencies. Disclosure is a means of mitigating these problems. Therefore, a positive relationship between government ownership and disclosure is expected (Eng \& Mak, 2003). Contrastingly, the capital need theory assumes that companies with high governmental ownership may not be motivated to raise their capital by releasing voluntary information due to the availability of government funding and also other financial resources. Xiao et al. (2004) observed that companies characterised by government ownerships are less motivated to maintain a healthy demand for shares.

Consistent with the two opposing perspectives, there is evidence illustrating mixed results on the association between government ownership and voluntary disclosure. Some studies (Xiao et al., 2004) had reported a negative relationship between higher government agencies' ownership and website information disclosure. Other studies (Kelton \& Yang, 2008; AbuGhazaleh, Qasim, \& Roberts, 2012) demonstrated that there was a positive and significant relationship between government ownership and the IFR. Although the role of government ownership is substantial in the GCC countries (Al-Khouri, 2012), its impact on the IFR disclosure has not been thoroughly explored. To the best of our knowledge at the time this study was conducted, only one study (Momany \& Pillai, 2013) had explored the impact of government ownership on the IFR in the GCC setting. Using data extracted from 65 companies listed on the Abu Dhabi Securities Exchange (ADX), Momany and Pillai (2013) evaluated the extent of these companies' IFR. Their results revealed that 89 per cent of the quoted companies had websites and 60 per cent of the companies that had websites 
presented their financial information on the websites. The findings also revealed that profitability and corporate governance were significant determinants of the IFR. In relation to government ownership, there was no evidence to indicate that government ownership was associated with the IFR among companies in the United Arab Emirates. Nevertheless, the findings in Momany and Pillai (2013) were based on a small sample size and a dummy variable to proxy for the dependent variable. Our study seeks to contribute to literature by expanding and improving on the evidence of these past studies.

Overall, literature suggests that there are two possible ways on how government ownership can affect the IFR - from the theoretical perspective and from empirical evidence. As an external governance mechanism, the monitoring role of government ownership may likely encourage IFR practices due to the need to reduce the high agency costs arising from such ownerships. However, government ownership corporations may have a less desire to promote the IFR since there are less pressures to gain capital from the larger market. In the context of the GCC countries, there is a relatively large government stake in the listed companies (Santos, 2015). This can trigger various concerns. On the one hand, firms with highly concentrated government ownership would need to be more transparent to legitimise the support that they might have received from the government. On the other hand, these companies might feel less pressured to make substantial disclosures due to their position of being in secure positions as governmentbacked companies. In this study, we focus on government ownership and family ownership structures so as to unravel the dilemma, and accordingly, contribute to the discipline. Our focus on government ownership is in line with the need to explore the agency costs arising from concentrated ownership rather than the role of management, which is more apparent in the GCC countries. In line with the inconclusive findings that have been discussed above, we posit that government ownership does affect corporate disclosure practices via the IFR. Thus, the hypothesis formulated is as follows:

$\mathrm{H}_{1}$ : There is an association between government ownership and the level of IFR.

\subsubsection{Family Ownership and IFR Disclosure}

Companies characterised by concentrated and controlling ownerships such as family ownership, may be reluctant to provide voluntary dis- 
closures. This is because as a family, the owners in these companies have alternative ways (inside) of getting information (Wang, Ali \& Al-Akra, 2013; Al-Shammari, 2007). In the context of company concentration as characterised by family ownership, Fleming, Heaney and McCosker (2005) argued that the agency costs of a firm decrease as family ownership increases. Family-controlled companies have little motivation to disclose information in excess of mandatory requirements because the demand for public disclosure is relatively weak in comparison to companies that have wider ownership (Chau \& Gray, 2002). Family ownership may impede the quality of disclosure because a listed company with a controlling family member on the board tends to have less transparent disclosures in its annual report (Ho \& Wong, 2001).

Mixed findings had been reported showing the association between family ownership and IFR. Thangatorai, Jaffar and Shukor (2013) reported that the existence of family members sitting in the corporate board tends to be negatively related to IFR disclosures. Nonetheless, Ali, Chen and Radhakrishnan (2007) found that there was a positive relationship between family companies and financial disclosures. This is also endorsed by Wan-Hussin (2009) and Wang (2006). Using data taken from 179 companies listed on the Kuwait Security Market to examine the IFR and its determinants, Alanezi (2009) found that 56 per cent of the sampled companies presented their financial reports on their websites. The findings also showed a significant and positive relationship between IFR and firm size, auditing type and industry type. However, Alanezi (2009) did not find any evidence to support his hypothesis stating that Kuwaiti companies with a higher proportion of dominant family members on the board were less likely to engage in IFR disclosures.

Thus, while theoretical perspective indicates that companies with high family ownership have less pressure but needs greater disclosure due to the lower agency costs surrounding these companies, evidence from prior studies (Thangatorai et al., 2013; Ali, et al., 2007; Alanezi, 2009) has been inconclusive. This implies that there is a need to improve the understanding and to clarify the issue regarding the role of corporate governance from the perspective of family ownership. On one hand, firms with high family ownership may want to publicly reveal more information so as to justify and retain their position in the capital market. On the other hand, there are tendencies for family owners to be firmly entrenched in the running of their companies, and so less disclosure is a way to cover up their entrenchment. In the 
GCC countries, companies are mainly dominated by families (Chahine, 2007; Baydoun et al., 2013; Santos, 2015). This makes the environment a perfect setting to explore on to understand how one type of concentrated ownership structure may characterise the many emerging economies. A higher concentration of family ownership in corporations or companies suggests that the appointment of family members onto the company board may not necessarily be based on merit. Rather, it could be due to the linage, loyalty and informal/personal relationship with the owners of the firm. While companies with family ownership may have the tendency to look after the interests of large shareholders (Baydoun et al., 2013), the assumption has not been sufficiently tested. By focussing on the role of governance from the perspective of family ownership, our study will contribute to the understanding of agency cost that arises from concentrated ownership related to families. The finding may be crucial especially for the emerging economies of the GCC region. As findings on the association between family ownership and IFR have been inconclusive, we hypothesise that family ownership does affect the IFR of companies in the GCC countries. Thus, the hypothesis formulated is as follows:

$\mathrm{H}_{2}$ : There is an association between family ownership and the level of IFR.

\subsection{Internet Penetration and IFR}

Aside from company-level factors, the differences in the institutional environment across countries can also explain the variations in IFR. In general, the institutional environment surrounding each country creates different managerial incentives that shape the behaviour of corporate executives, investors, regulators, and other market participants (Bushman \& Piotroski, 2006). In this regard, the strategic decisions involving disclosure and transparency of financial information through the IFR is likely to be influenced by such institutional factors. This outcome is comparable to how regulations and enforcement in different countries influence the development of accounting standards and practices (Saudagaran \& Diga, 1997) and shaping the quality of their financial reporting (e.g. Ball, 2006). In the context of the GCC countries, issues associated with the institutional environment have become particularly important when it involves the IFR. The Internet has witnessed a rapid spread across the Middle East in the twentyfirst century (Alqudsi-ghabra et al., 2011). This development suggests 
that the Internet meets the demand of both the companies and the stakeholders. Looking at the companies of the GCC countries, it appears that the Internet has also worked towards enhancing their local and global recognition. From the perspective of the stakeholders such as shareholders, clients and suppliers, it appears that the Internet is very much utilised to seek information for effective and efficient decisionmaking. Nonetheless, the case of the IFR disclosure may be viewed as an innovative adoption. This can be explained by using the diffusion of innovation theory. According to this theory, organisations differ with respect to innovations adoption. Chircu and Kauffman (2000) indicated that companies encounter a number of barriers in adapting information technology. The barriers may be related to the valuation of the information technology process (organisational barriers) or to the conversion from the current situation to a new one (user barriers).

Studies (e.g. Isidro \& Raonic, 2012; Leuz, Nanda, \& Wysocki, 2003; Bushman \& Piotroski, 2006) using data from multiple countries have suggested that variations in the institutional environment affect the quality of financial reporting. Xiao et al. (2004) had also asserted that the development of technological innovation such as the emergence of the Internet has an impact on accounting information practices. The Internet penetration rate, which can be inferred from the percentage of Internet users in the entire population of a country, is one method of measuring the technology which also indicates human development. In their study, Debreceny et al. (2002) argued that countries with a heavy penetration of Internet usage tend to have many companies adopting the IFR as a means of disseminating financial disclosures. They stated that from the users' perspective, a high level of Internet penetration at the country level leads to more demand for the IFR. From the suppliers' perspective, the Internet acts as a conduit for a more efficient dissemination of information. Pervan (2006) also pointed out that companies can satisfy investor needs for information quickly and cheaply through the Internet. This reporting environment allows investors to be updated constantly. In contrast, the inducement for the IFR is likely to be low if investors do not use the Internet very frequently.

The need to examine the impact of institutional environment on the IFR, particularly when related to the Internet revolution, is justified. Undoubtedly, the ability to capitalise on the full benefit of the IFR relies on the infrastructure that promotes, facilitates and enables the efficient dissemination of information. A supportive environment makes 
it easier for companies to transmit transparency, thereby encouraging greater reporting of financial information. In the context of the GCC countries, it is observed that the pace of change related to the number of reported Internet users is impressively expanding but the utilisation of the Internet as a potential medium of communication has not been fully exploited. This is traced to Elmasry, Benni, Patel and Moore (2016) who asserted that businesses and governments have not fully embraced the digital opportunity yet while consumers are primed and ready to lead a digitally enhanced live. Studies (Debreceny et al., 2002; Ojah \& Mokoaleli-Mokoteli, 2012) who had examined the relationship between Internet penetration and the IFR had produced inconclusive results. Debreceny et al. (2002) predicted that the IFR vary according to the level of Internet penetration. However, their prediction was not supported by the results of their studies. Likewise, Pérez, Bolívar and Hernández (2008) found that the Spanish public sector with Internet promotion policies tended to provide more financial-budgetary information. Ojah and Mokoaleli-Mokoteli (2012) also found that, aside from corporate governance structure, physical and institutional infrastructures are important determinants of a country's adoption of the IFR. Their analysis, derived from companies recruited from 44 developed and developing countries, showed that Internet penetration has a positive significant association with IFR disclosures.

This study looks at voluntary financial reporting via the Internet. It focusses solely on Internet penetration rate as a country-level institutional factor that influences the IFR. While the IFR benefits companies, the adoption of the IFR may be subjected to other constraints related to the institutional framework surrounding the companies. Accordingly, IFR studies have to consider the fact that there are countrylevel institutional factors that may hamper the development of the IFR in a particular country despite the advantages offered. Our focus on Internet penetration rate is warranted by the fact that GCC countries, despite sharing many sociocultural and institutional similarities, have various levels of Internet penetration rates (Alqudsi-Ghabra et al., 2011). Although it is possible that companies in countries with heavy penetration of Internet usage are more likely to adopt the IFR as compared to companies in countries with low penetration of Internet usage, prior studies (e.g. Debreceny, et al., 2002) have showed mixed results. As such, there is a need to further investigate the impact of the Internet penetration on the IFR. In line with Debreceny et al., (2002), this 
study hypothesises that the level of Internet penetration influences the adoption of the IFR. Thus, the hypothesis formulated is as follows:

$\mathrm{H}_{3}$ : There is an association between Internet penetration and the level of IFR.

\subsection{Ownership, Internet Penetration, and IFR}

The discussion in section 2.3 posits that corporate ownership structure influences the IFR. This view is consistent with the observation that IFR practices are dependent on the quality of the external governance of government and family ownerships. The discussion in section 2.4 indicates that institutional environments such as the Internet penetration rate plays a critical role in the IFR decisions of companies (Debreceny et al., 2002; Pervan, 2006) especially in emerging economies (Ojah \& Mokoaleli-Mokoteli, 2012). However, both discussions had focussed mainly on the direct effect of the governance mechanism and Internet penetration. They seemed to have overlooked the fact that there are interdependencies between the organisations and their diverse environments which could affect the effectiveness of the different governance practices (Aguilera, Filatotchev, Gospel, \& Jackson, 2008; Bushman \& Piotroski, 2006; Leuz et al., 2003). Using data from various countries, Samaha and Dahawy (2010) have noted the joint effect of firmlevel and country-level governance on the capital market. Based on this insight, it seems imperative for models to be built by including countrylevel factors since company-level factors may not be sufficient for explaining the level of voluntary disclosure (Ojah \& Mokoaleli-Mokoteli, 2012). In the context of the IFR, Bowrin (2015) has suggested that researchers look at both the country and company-level characteristics when seeking to explain the IFR. Addressing the recommendations of these prior studies (e.g. Bowrin, 2015), we thus endeavour to examine the interrelationship between company-level governance and countrylevel Internet penetration in influencing the IFR practices of companies in the GCC countries.

In theory, there are two possible ways in which company-level governance and country-level institutional factors interact in determining strategic decisions involving the IFR. From the complementary role perspective, the presence or addition of one mechanism strengthens and this leads to more effective governance in addressing agency problems (Ward, Brown, \& Rodriguez, 2009). From the substitutability 
role perspective, an increase in one mechanism can directly replace a portion of the other mechanism while the overall functionality of the system remains the same (Ward et al., 2009). While the ownership structure can determine the level of voluntary disclosure of financial information through the Internet, home-country environments may still have some determining power over the IFR. Thus, the joint effect of the Internet penetration of the home country and corporate ownership structure on the IFR remains an empirical dilemma. It appears that variations in the countries' Internet penetration can influence the impact of corporate ownership on the IFR and this, inevitably, generates variations in the IFR across companies in different countries.

Likewise, the effect of company-level governance on financial reporting quality can also be subjected to the institutional environment within which companies operate. Studies (Francis, Khurana, \& Pereira, 2005; Webb, Cahan, \& Sun, 2008; Ariff, Cahan, \& Emanuel, 2014) have looked at companies from various countries. Their findings indicated that the interaction between company-level and country-level factors should be considered when analysing the variation in companies' voluntary disclosure (Francis, Khurana, \& Pereira, 2005; Webb, Cahan, \& Sun, 2008). In their study, Ariff, Cahan and Emanuel (2014) examined the voluntary disclosures of intangibles in eight East Asian countries. Their findings showed that the value relevance of disclosures is conditional on the level of director ownership and the strength of the institutional features of a country. Studies such as Debreceny et al., (2002) added to the understanding of the combined effect of companylevel governance and the varying strength of country-level mechanism on strategic voluntary decisions related to corporate reporting. In the context of the Internet penetration, we recognise (as shown in Table 2) that there are large variations in the level of Internet penetration across the GCC regions. Since high quality Internet penetration enhances the demand for IFR disclosures (Debreceny et al., 2002), there are possibilities that variations may exist in the effect of governance on IFR practices across companies in countries with different levels of Internet penetration. In short, while governance affects the IFR practices, the effect may be conditional based on the level of Internet penetration.

Based on the above discussion, we predict that the role of governance on the adoption of the Internet as a tool for information disclosure, is subject to the level of Internet penetration. From a complementary role perspective, favourable Internet penetration mitigates the negative effect of ownership structure on IFR. In our study, a 
greater level of Internet penetration (if any) will reduce agency costs that arise from the weak monitoring of government/family ownership (if any), thereby improving IFR. From the substitutability perspective, there is no difference in the link between ownership structure and the IFR of companies' location (whether in more favourable or less favourable environment). In the context of our study, the benefits drawn from a greater level of Internet penetration (if any) replaces the weak monitoring role of the government/family ownership (if any), thereby resulting in the indifferent effects on IFR. More specifically, it is expected that if there is any association between government/family ownership and the level of IFR, the association will be stronger (if positive) or weaker (if negative) for companies with a better Internet penetration environment. Thus the hypotheses formulated are as follows:

$\mathrm{H}_{4 \mathrm{a}}$ : The association between government ownership and the level of IFR is moderated by Internet penetration.

$\mathrm{H}_{4 \mathrm{~b}}$ : The association between family ownership and the level of IFR is moderated by Internet penetration.

\section{Method}

\subsection{Research Sampling}

The samples of this study comprise financial companies extracted from the GCC countries. This is because the GCC countries share a number of specific structural economic features that unite them under a common umbrella. Hence, the reason for previous studies to deal with them as one region (see, Yusof \& Bahlous, 2013). As discussed in Section 2.1, our focus on financial companies is warranted by the fact that the financial sector has special relevance for the economy of the GCC countries. The advantage of using a single industry (e.g., financial sector in this study) is that the homogeneous nature within one industry generates a better control of the industry context and market level influence (Pollalis, 2003).

In selecting the samples, we first include all financial companies listed in the GCC countries as the population frame. There was a total of 243 financial companies listed in the stock market of the GCC countries at the end of 2012. However, after checking out their online presence, five were excluded from the initial sample because their websites were inaccessible or under construction. In addition, inadequate data related to corporate governance reduced the initial sample to 152 companies. We have to exclude all the companies from Kuwait due to 
missing corporate governance information. The exclusion is in line with the findings of Al-Malkawi, Pillai and Bhatti (2014) who noted that companies listed in the Kuwait stock market had exhibited the worst adherence to corporate governance mechanisms. The final sample thus comprised 21 companies from Bahrain, 26 companies from Oman, 15 companies from Qatar, 43 companies from Saudi Arabia, and 47 companies from the United Arab Emirates ( $n=152)$.

A secondary data method was employed to gather relevant data for the year 2012. This is because 2012's annual reports served as the latest source of information available, at the time this study was initially conducted. Data for the dependent variable were manually collected from the companies' websites while data for the independent variables were manually collected from the annual reports of the companies. To gather data of the dependent variable from the website, the web pages of the companies were inspected and examined in detail prior to obtaining information. Since company web pages are dynamic in nature, the objective was thus to collect data within a specific time period. Following the strategy employed by previous studies (e.g., AlHtaybat, 2011; Ali-Khan \& Ismail, 2011), inspections of the companies' websites were also done twice. The first inspection was in November and December 2012 and the second inspection was in March 2013. The second inspection was aimed at correcting any error before the final score was computed as well as to enhance the validity and reliability of the current checklist.

\subsection{The Research Models and Variables}

In relation to the hypotheses set above, the framework and the variables of this study are depicted in Appendix A and B respectively. Two multivariate models were estimated for this study. In the models, the IFR is the level of Internet Financial Reporting, GOVOWN is Government ownership, FAMOWN is Family ownership, INTNET is Internet penetration, FSIZE is Firm size, ROA is Profitability, LEV is Leverage, BIG4 is Auditing by Big 4 accounting companies, GOVOWN*INTNET is the moderating variable for government ownership and Internet penetration, and FAMOWN*INTNET is the moderating variable for family ownership and Internet penetration. The equation is as below.

$$
\begin{aligned}
I F R= & a+\beta_{1} \text { GOVOWN }+\beta_{2} \text { FAMOWN }+\beta_{3} I N T N E T+ \\
& \beta_{4} \text { FSIZE }+\beta_{5} R O A+\beta_{6} L E V+\beta_{7} B I G 4+\varepsilon
\end{aligned}
$$


In Model 1 , the coefficients of $\beta_{1}, \beta_{2}$ and $\beta_{3}$, represent the association between GOVOWN, FAMOWN and INTNET with IFR. It is used to test $\mathrm{H}_{1}, \mathrm{H}_{2}$, and $\mathrm{H}_{3}$ respectively and to identify whether government ownership, family ownership and Internet penetration affect Internet Financial Reporting.

$$
\begin{aligned}
\text { IFR }= & a+\beta_{1} \text { GOVOWN }+\beta_{2} \text { FAMOWN }+\beta_{3} \text { INTNET }+\beta_{4} \text { FSIZE }+ \\
& \beta_{5} \text { ROA }+\beta_{6} \text { LEV }+\beta_{7} \text { BIG }+\beta_{8} \text { GOVOWN } \text { INTNET }+^{*} \\
& \beta_{9} \text { FAMOWN } \text { INTNET }+\varepsilon^{*}
\end{aligned}
$$

Model 2, which is the fully specified model is used to test $\mathrm{H}_{4}$. In the equation of Model 2, $\beta_{8}$ and $\beta_{9}$ test for the incremental effect of INTNET on the association between GOVOWN and IFR, and FAMOWN and IFR, respectively.

IFR, which is our dependent variable, is the level of IFR. An index was developed in order to measure the extent of IFR in the websites of the 152 companies. The index was derived based on the attributes identified in previous works (e.g. Xiao et al., 2004; Kelton \& Yang, 2008; Arussi, Selamat, \& Hanefah, 2009; Desoky 2009; Aly, Simon, \& Hussainey, 2010; Al-Htaybat, 2011). The disclosure index in this study, which is closely similar to the IFR index used by Desoky (2009), consists of the IFR content and the IFR presentation format. The IFR content refers to the type of published financial information or the availability of company financial information displayed in the company's website (Lybaert, 2002; Xiao et al., 2004) while the IFR presentation format concerns the way in which the content and the navigation facilities are presented to the user (Bonsón-Ponte, Escobar-Rodriguez, \& FloresMunoz, 2008). As shown in Appendix C, our index incorporates a total of 35 items. Unweighted checklists were constructed to measure the level of the IFR of the financial companies listed in the GCC countries. This procedure is consistent with prior studies (Abdelsalam et al., 2007; Kelton \& Yang, 2008) which also supported the unweighted scoring approach. A score of ' 1 ' is assigned for the presence and ' 0 ' for the absence of each item of content. The total score for each company is measured as the percentage of the actual score awarded to the maximum possible score, which is 35. Following Bonsón and Escobar (2006), the total score is based on a simple aggregation such that the value of the index utilised is the result of summing the scores assigned to each category of information.

We used two measures of ownership structure, GOVOWN and FAMOWN, by referring to the percentage of ordinary shares held by 
substantial shareholders (government and family). The GCC stock exchanges require the disclosure of ownership for each individual, corporation or government that owns 5 per cent or more (Al-Shammari, Brown, \& Tarca, 2008). Following the approach used by Chahine (2007), AbuGhazaleh et al. (2012) and Al-Musalli and Ku Ismail (2012), we likewise employed the aggregate proportion of ordinary shares (5 per cent or more) owned by substantial shareholders of these groups, as disclosed in the annual reports at the end of 2012.

The INTNET or Internet penetration, is the percentage of a population using the Internet and this is derived from the Internet World Statistics in 2012 (details are shown in Table 2). Following Debreceny et al. (2002), this study uses the quintile ranks of each country as the measure for Internet penetration (INTNET). This is done by giving a value of 1 to the lowest quintile and 5 to the highest quintile of national Internet penetration. In this regard, the Qatari companies were ranked the highest for Internet penetration and so assigned a score of 5 . This is followed by the Bahraini companies, with a score of 4, the UAE companies with a score of 3 , the Omani companies with a score of 2, and the Saudi Arabian companies with a score of 1 . The GOVOWN*INTNET and the FAMOWN*INTNET were the interaction variables, between government ownership and Internet penetration, and family ownership and Internet penetration, respectively. The interaction variables were used to identify the moderating effect of the Internet penetration. We applied the moderated multiple regression approach because it is the most preferred technique in testing the moderating effect due to issues regarding subgroup effect techniques such as unequal sample sizes and error variances across groups (Aguinis \& Gottfredson, 2010).

Control for other factors that may affect the IFR was done by incorporating the companies' characteristics in the regression model. We control firm size (FSIZE), profitability (ROA), leverage (LEV), and auditor (BIG4). FSIZE is the natural logarithm of the book value of the total assets, a measurement that is consistent with prior studies such as Abdelsalam et al. (2007), and Alanezi (2009). We expect a positive relationship between FSIZE and IFR, following findings of previous studies such as Alali and Romero (2012). The ROA or return on assets was calculated by dividing the net profit or loss by total assets. This measurement was used previously by many studies (e.g., Xiao et al., 2004; Abdelsalam et al., 2007; Alanezi, 2009) and a positive coefficient is expected. The LEV is the ratio of the total debt to total assets, developed in line with prior studies (e.g., Chahine, 2007). Due to inconsistencies 
in the findings of past studies (e.g. Aly et al., 2010; Alali \& Romero, 2012), there is no direction set on the association between LEV and IFR. The BIG4 was measured by using a dummy variable of one (1) if the company is audited by the BIG4 audit companies and zero (0) if otherwise. We followed the approach of previous studies such as Aly et al. (2010) and AbuGhazaleh et al. (2012). Empirically, the findings of prior studies (e.g., Agboola \& Salawu, 2012; Momany \& Pillai, 2013) looking at the relationship between audit firm and IFR practices had been mixed. Thus, no direction is set on the association between the BIG4 and the IFR.

\section{Results and Discussion}

\subsection{Descriptive Statistics}

As illustrated in Table 1, the mean level of the IFR is 0.58 with a median of 0.60 . On average, a company discloses 58 per cent of the 35 items included in the index. The highest and lowest scores of the IFR was 91 per cent and 9 per cent respectively. The wide range of 82 per cent in the level of IFR indicates a substantial variation in the IFR across the sample companies. None of the companies disclosed 100 per cent of the 35 index items that were applicable to them. This therefore highlighted the opportunity for further improvement to the IFR practices.

Focussing on the ownership structure, Table 1 suggests that the listed financial companies of the GCC countries are highly concentrated. Focussing on government ownership, the statistics in Table 1 illustrates the minimum value ( 0 per cent) and maximum value ( 80 per cent) of the government ownership (GOVOWN) with an average value of 8.2 per

Table 1: Descriptive Statistics of Variables

\begin{tabular}{lrrrrrr}
\hline Variables & Min. & Max. & Mean & Median & Range & Std. Dev \\
\hline IFR & 0.090 & 0.910 & 0.582 & 0.600 & 0.820 & 0.198 \\
GOVOWN & 0.000 & 0.800 & 0.082 & 0.000 & 0.800 & 0.161 \\
FAMOWN & 0.000 & 0.790 & 0.120 & 0.050 & 0.790 & 0.170 \\
FSIZE & 6.880 & 11.000 & 8.863 & 8.510 & 4.120 & 0.977 \\
LEV & 0.030 & 1.000 & 0.625 & 0.672 & 0.970 & 0.237 \\
ROA & -0.100 & 0.100 & 0.025 & 0.021 & 0.200 & 0.033 \\
\hline
\end{tabular}

Note: IFR $=$ the level of IFR, GOVOWN = Government ownership, FAMOWN = Family ownership, FSIZE = Firm size, LEV = Leverage, and ROA = Profitability. 
cent and a median value of 0 per cent. In looking at family ownership (FAMOWN), the minimum and maximum values were 0 per cent and 79 per cent, respectively. With respect to the control variables, Table 1 presents an analysis of firm size (FSIZE) as measured by a log of the companies' total assets. The mean and median were $\$ 8.86$ and $\$ 8.51$, respectively, with a minimum value of $\$ 6.88$ and a maximum value of $\$ 11$. As for leverage (LEV), the mean and median values were 62.5 per cent and 67.2 per cent, respectively. With respect to profitability (ROA), the sample has an average profitability level of 2.5 per cent, with a minimum value of -10 per cent, a maximum value of 10 per cent, and a median value of 2.1 per cent. The negative sign of the minimum value (-10 per cent) of the ROA indicates that some of the sample companies had experienced a loss during the investigation year.

Table 2 summarises the Internet penetration and the IFR among the GCC countries. As illustrated, Qatar has the highest Internet penetration, at 0.853 whereas Saudi Arabia has the lowest Internet penetration, at 0.490. Comparing this to the IFR for companies in the GCC countries, the highest median for the IFR was shown for Qatar, with a score of 0.770 whereas Saudi Arabia was shown to have the lowest median of the IFR, with a score of 0.540 . The results indicate that there were variations in the level of Internet access among the GCC countries. The results also indicate that the IFR level and the Internet penetration level of these countries varied. It seems apparent that despite their sociocultural and institutional similarities, the GCC countries varied in terms of the sophistication of the environment in which their companies operated. The results supported the findings of Debreceny et al. (2002) who

Table 2: Descriptive Statistics of Internet Penetration and IFR among the GCC Countries

\begin{tabular}{lccc}
\hline Country & Frequency & Internet Penetration & IFR \\
\hline Bahrain & 21 & 0.770 & 0.690 \\
Oman & 26 & 0.688 & 0.570 \\
Qatar & 15 & 0.853 & 0.770 \\
KSA & 43 & 0.490 & 0.540 \\
UAE & 47 & 0.709 & 0.540 \\
\hline Total & 152 & 0.670 & 0.600 \\
\hline
\end{tabular}

Note: Internet World Statistics (in December, 2012) at www.Internetworld stats.com 
mentioned that Internet penetration is an environmental variable that creates demand for the IFR. This also explains the variations that exist among corporate practices involving the IFR.

\subsection{Univariate Analysis}

Pearson's correlation analysis was performed in order to check the correlation between the variables (untabulated for brevity). The results highlighted the significant positive correlation between the dependent variable (IFR) and government ownership (GOVOWN), at the 5 per cent level. The results also indicated a significant negative correlation between the IFR and family ownership (FAMOWN), at the 1 per cent level. The results further showed that there was a significant positive correlation between the IFR and the Internet penetration (INTNET), at the 1 per cent level. Looking at the correlation between the dependent variable and the control variables, the results further illustrated that firm size (FSIZE) and profitability (ROA) have a significant positive correlation with the IFR, at the 1 per cent and 5 per cent levels, respectively. A negative significant correlation was noted between leverage (LEV) and the IFR, at the 5 per cent level. In contrast, the BIG4 showed no correlation with the IFR disclosure. Pearson's correlation analysis was also performed to investigate whether multicollinearity is a problem in our analysis. The results suggested that multicollinearity was not a problem because none of the level of correlation exceeded 0.90 (Hair, Black, Babin, \& Anderson, 2010).

\subsection{Regression Analysis Results}

The main regression results are presented in Table 3. Columns 3 and 4 display the results based on the specification in Model 1 and columns 5 and 6 display the results based on the specification in Model 2. For Model 1, the adjusted $R^{2}$ is 0.463 and the F-ratio is 19.584 . There was a significance of $p<0.001$. For Model 2 , the adjusted $R^{2}$ is 0.494 , indicating that 49 per cent of the variation in the level of IFR disclosures of the sampled companies is explained by the explanatory variables of this model. The F-ratio of the first model is 15.381 , with a significance of $p<0.001$. These results indicate that the overall model is well fitted.

Columns 3 and 4 in Table 3 present the results for the variables related to ownership: governmental ownership (GOVOWN) and family ownership (FAMOWN). Both were used to analyse the individual 
Table 3: Regression Analysis Results

\begin{tabular}{|c|c|c|c|c|c|}
\hline \multirow{2}{*}{ Variables } & \multirow{2}{*}{$\begin{array}{l}\text { Expected } \\
\text { Sign }\end{array}$} & \multicolumn{2}{|c|}{ Model 1} & \multicolumn{2}{|c|}{ Model 2} \\
\hline & & Coefficients & $t$-stat & Coefficients & $t$-stat \\
\hline Constant & & & -5.386 & & -4.203 \\
\hline GOVOWN & $+/-$ & $-0.153^{* *}$ & -1.824 & -0.107 & -1.545 \\
\hline FAMOWN & - & $-0.271^{* * *}$ & -3.775 & $-0.226^{* *}$ & -3.500 \\
\hline INTNET & + & $0.405^{* * *}$ & 3.769 & $0.231^{* *}$ & 3.140 \\
\hline FSIZE & + & $0.122^{* \star *}$ & 7.728 & $0.570^{* * *}$ & 6.881 \\
\hline ROA & + & $-0.768^{* *}$ & -2.034 & $-0.137^{\star *}$ & -2.175 \\
\hline LEV & $+/-$ & -0.031 & -0.511 & -0.029 & -0.400 \\
\hline BIG4 & $+/-$ & 0.039 & 0.579 & 0.040 & 0.650 \\
\hline GOVOWN*INTNET & $+/-$ & & & -0.075 & -1.177 \\
\hline FAMOWN*INTNET & $+/-$ & & & -0.055 & -0.746 \\
\hline Adjusted $\mathrm{R}^{2}$ & & \multicolumn{2}{|c|}{0.463} & \multicolumn{2}{|c|}{0.494} \\
\hline F Change & & \multicolumn{2}{|c|}{$19.584^{* * *}$} & \multicolumn{2}{|c|}{$15.381^{* * *}$} \\
\hline
\end{tabular}

Note: ${ }^{* * *} p<0.01,{ }^{* *} p<0.05,{ }^{*} p<0.10$. IFR $=$ the level of IFR, GOVOWN $=$ Government ownership, FAMOWN = Family ownership, INTNET = Internet penetration, FSIZE $=$ Firm size, LEV $=$ Leverage, and ROA $=$ Profitability, Big4 $=$ Audited by Big 4.

effect of the corporate governance mechanisms on the IFR of the GCC countries. Table 3 also presents the results for the individual effect of the Internet penetration (INTNET). For government ownership, the statistical results revealed that government ownership (GOVOWN) has a negative and significant relationship with the IFR. This implies that listed financial companies in the GCC countries with higher proportions of government ownership disclosed a lower amount of information on their websites. This negative association contradicts the positive correlation shown in the Pearson's correlation analysis above. Nevertheless, Pearson only tests correlations between two variables, without considering other variables that may explain the dependent variable. Regression analysis, on the other hand, provides a more accurate view of the association between government ownership and the IFR. The empirical results of GOVOWN supported the capital need theory. The results were also consistent with the findings of Xiao et al. (2004) which looked at Chinese companies and Desoky 
(2009) which looked at Egyptian companies. Comparing our current findings to those of Momany and Pillai (2013) who found no significant association between government ownership and the IFR in the United Arab Emirates, we believe that our findings have provided a more comprehensive view about the role of government ownership in the GCC countries. Our claims are based on our samples that were derived from listed financial companies located in the countries of the GCC region (except for Kuwait). We believe we have addressed the limitation noted in Momany and Pillai (2013) by using a bigger sample size and a more comprehensive index to measure the IFR. Accordingly, the first hypothesis which state that there is a relationship between government ownership of financial companies in the GCC and IFR is supported. The results thus imply that companies with higher government ownership suffer from low level IFR.

From the family ownership perspective, the regression analysis results displayed a negative association between FAMOWN and IFR. These results indicated that financial companies listed in the GCC countries with a large percentage of shares held by family ownership, were more likely to have a lower amount of information on their websites. The results are in line with the findings of previous empirical studies (e.g. Ali et al., 2007; Chau \& Gray, 2010). Looking at Kuwaiti companies, Alanezi (2009) did not find any association between family ownership on the IFR. In contrast, our study had shown that companies with higher family ownership suffered from low level IFR. We believe that our findings portray a picture demonstrating the significant effect of family ownership in GCC countries. It appears that the effect of family ownership on the IFR is substitutive; family ownership decreases the firm's need for additional monitoring through disclosure transparency. In line with the agency theory, there is no need for the burden of potential costs gained from maintaining an investor relation's page on the Internet, to disclose more information. This is because family shareholders have superior access to corporate information (Leuz \& Verrecchia, 2000). Thus, the need for a corporate disclosure tool (e.g. IFR disclosure) to mitigate agency costs is not necessary because the owners themselves have better access to internal information. In this regard, Hypothesis 2 which assumes a negative relationship between family ownership and IFR disclosure is supported.

Looking at Internet penetration, the results showed that Internet penetration (INTNET) is a significant positive indicator for IFR disclosure. It was observed that the IFR was higher for financial companies 
with greater Internet penetration. These results are consistent with the view that accounting systems, including financial reporting practices, differ from country to country due to the relative influence of their environmental factors (Cooke \& Wallace, 1990). The positive relationship between INTNET and IFR disclosure is thus consistent with the diffusion of innovation theory which suggests that companies may accept new technologies (i.e. Internet) due to fad and fashion perspectives. In this regard, it is assumed that companies in a group imitate other companies in the same group or outside the group in order to reduce uncertainty and to appear legitimate (Abrahamson, 1991; Xiao et al., 2004). Due to the practice of organisational imitations, it can be noted that financial companies listed in GCC countries with higher Internet penetration were more likely to adopt the Internet as a tool for disseminating timely information. In this regard, Hypothesis 3 which assumes a positive relationship between Internet penetration and IFR disclosure is supported.

Columns 5 and 6 of Table 3 show the results of the fully specified model. The results related to GOVOWN, FAMOWN and INTNET appeared slightly different once we allow for the coefficients to vary with the country's Internet penetration, as noted in Model 2. For government ownership, we observe no statistical evidence to indicate that GOVOWN is associated with IFR, unlike the significant results shown by Model 1. For family ownership, the results in columns 5 and 6 display a significant and negative association between FAMOWN and IFR, similar to Model 1. For Internet penetration, the results were also similar to Model 1 because the coefficient for INTNET is significant and positive. The interaction variables, GOVOWN*INTNET and FAMOWN*INTNET were used to examine the moderating effect of Internet penetration on governance mechanisms.

The results relating to the moderating effect of Internet penetration for both government ownership and family ownership, nonetheless, were not in line with the expectations set in our hypothesis. For government ownership, we observe no statistical evidence to indicate that INTNET moderated the effect of GOVOWN on IFR. Logically, because GOVOWN itself is not significant in Model 2, the coefficient of GOVOWN*INTNET is not expected to be of any use. With regards to family ownership, we observe no statistical evidence to support the moderating effect of INTNET on the association between FAMOWN and IFR. Therefore, family ownership is associated with lower IFR practices by companies, regardless of the Internet penetration of the 
countries. Accordingly, Hypotheses $4 \mathrm{a}$ and $4 \mathrm{~b}$ were not supported. We offer several possible explanations for these insignificant results. We infer that the insignificant findings were related to the possibility that the weaknesses of ownership structure, sourced from government and family, prevailed over the benefit of Internet penetration in influencing the IFR. While Internet penetration facilitated the IFR, there were other institutional factors that could have greater influence on governance decisions involving the IFR. These factors could be related to technological factors such as cyber security risks in a particular country. We address this issue as the limitation of our study and we offer suggestions for future research in the conclusion section.

With respect to control variables, the results in Table 3 shows that the coefficient of FSIZE is positive and significant $(t=6.881, p=0.000)$. The positive effect of firm size on IFR suggests that the larger companies were more likely to utilise the Internet for information disclosure. The result involving FSIZE is consistent with many empirical studies (e.g. Evans, Henderson, \& Trinkle, 2011; Puspitaningrum \& Atmini, 2012). The coefficient of the ROA is shown to be negative and significant $(t=$ -2.175, $p=0.031$ ). Contrary to our prediction, the result involving the ROA may be linked to the possibility that higher profitability could drive rival companies to enter the same market (Álvarez, Sánchez, \& Domínguez, 2008). Consequently, companies with high profitability may disclose lesser information via the Internet so as to secure their competitiveness, especially within the context of emerging markets such as the GCC countries. The coefficients for LEV and BIG4 were not statistically significant. These results are in line with empirical studies (e.g. Aly et al., 2010; Alali \& Romero, 2012) which found an insignificant association between the proxies of leverage and auditor type and IFR disclosures.

Additional tests were conducted in order to check the robustness of the main results. Firstly, we employed dichotomous variables for GOVOWN and FAMOWN. The strategy was applied because the results derived from examining corporate governance characteristics on accounting proxies are sensitive to how these characteristics are measured (Carcello, Hermanson, \& Ye, 2011). Using alternate measures can help in checking the robustness of the results (Haniffa \& Hudaib, 2006). Secondly, we performed a separate analysis on two subsamples, the high and low Internet penetration. The results (untabulated for brevity) of these robustness tests indicate that our main results were robust to alternative specifications and measures. Consequently, the 
consistency in the results of the robustness test strengthen the validity of the findings and the recommendations drawn from them.

\section{Conclusion, Implication and Limitation}

This study has examined whether company-level governance and country-level institutional environment arising from Internet penetration, can jointly interact and be used to explain the variations in companies' IFR disclosure. An analysis was performed on a sample of 152 financial companies that were publicly listed in the stock market of the GCC countries in 2012. The focus on the GCC countries was motivated by the unique institutional settings of countries in the region, among which is the prevalent dilemma related to highly concentrated ownership by government and families. While the pressure to remain resilient and to improve the businesses and economies in the region is a motivating factor for disseminating information through the Internet, the role of governance on the IFR remains an empirical issue.

The results of this study documented a significant negative association between government and family ownership with IFR disclosure. The results pertaining to government ownership were consistent with the prediction of the capital need theory. In comparison, the results illustrating family ownership was in line with the agency theory. These findings imply that political ties and family involvement significantly influence companies in the GCC countries. More specifically, the significant involvement of government and families in the structure of corporate ownership may weaken the monitoring role of the board of directors in controlling and addressing various agency problems. In terms of policy indication, these findings had indicated that there is an urgent need for reforms to be established in the ownership structure of the financial sector in the GCC countries. Regulators should consider strengthening enforcing the legal protection of shareholders especially minority shareholders' interests.

The results of this study have also suggested that Internet penetration is a factor that influences the IFR. This outcome is consistent with the prediction of the diffusion of innovation theory. Our finding clarify the importance of access to the Internet among the GCC countries. This should motivate the GCC listed companies to disclose more information on their websites as the demand for such information increases. In order to maximise the potential economic developmental benefits of the Internet, GCC governments should be more responsive towards 
embracing changes; it should also consider adapting and investing in this media. Information and communication technology in the GCC must be promoted so as to facilitate the people's ability to connect online thereby, enhancing their global awareness. The lack of responsiveness in improving information and communication technology in the GCC countries may result in poor IFR practices. This may cause losses to domestic shareholders as well as foreign shareholders.

Nevertheless, our insignificant results illustrating the effect of Internet penetration on the association between governance and IFR may indicate that the incentives arising from company-level governance were more relevant in determining the quality of the IFR. Regardless of the level of a country's Internet penetration, the governance that is sourced from the highly concentrated ownership of government and families clearly influences IFR. Internet penetration also facilitates the use of the Internet in enabling a greater dissemination of information but it is not the only factor that can influence or overrule the incentive of the controlling owners on IFR decisions. In terms of implications to the management, there is a need for companies to consider other institutional factors that could have greater influence on such voluntary decisions. As highlighted by previous studies such as Xiao et al. (2004) and Jo and Jung (2005), financial disclosure and accounting information practices are subjected to a variety of environmental and technological factors such as cultural, political, economic and new technology developments like digital communication. Our findings also prompted academic implications by suggesting that the IFR is an important mechanism for corporate disclosure and transparency. As such, the accounting curriculum should be geared towards an assortment of issues that are associated with the IFR.

Accordingly, the insignificant findings derived from our fourth hypothesis may be related to the fact that we only employed Internet penetration as a country-level factor. This is because we believed that most other institutional factors of the GCC countries were similar. Future studies may need to examine other institutional factors of the GCC countries that could have more significant influence towards promoting IFR. Factors such as culture would be relevant for understanding corporate disclosure behaviour. Alternatively, technological factors such as cyber security risks is also pertinent.

Despite using the 2012 data, our findings have implications for the current scenario which encompass disclosure practices and corporate governance environment of the emerging economies, particularly the 
GCC countries. First, the pressure for companies to be more transparent through the IFR remains at the forefront, in the quest for investment opportunities among companies. As the GCC countries continue to struggle with economic diversification plans to remain resilient (Callen, Cherif, Hasanov, Hegazy, \& Khandelwal, 2014), there is a greater need to break through geographical borders in business operations and investment. The strategy to attract more funds from international investment communities relies on the ability of companies to showcase their future potentials through greater transparency and disclosure. Second, the role of good corporate governance is more important now in attracting foreign institutional investors to the GCC equity markets. Amico et al., (2016) had observed that improving the governance of businesses, particularly family-owned firms, the majority of which were non-oil economies in the Middle East, is a top concern for the region. Third, despite the fact that awareness for greater transparency and good corporate governance has developed gradually in recent years, its full adoption in the GCC countries is still minimal. This is attributed to the embedded conservativeness and protectionist investment culture of the region. Such practices also manifest a weak disclosure of information practices. This unwillingness to relinquish ownership and control by large blockholders may be disadvantageous to the economy in the long run. It is a challenge to separate ownership from management among the companies in the GCC countries. Since investors are ready to pay the premium for good governance in the emerging markets, there is a need for the GCC countries to strike an appropriate balance between their national approaches with internationally-recognised governance standards (Amico et al., 2016). Our findings, therefore, reinforce the importance of improving corporate governance environment which can enhance the disclosure practices of companies in the GCC countries.

Other than the limitations related to the proxy for countrylevel institutional factors, this study is also subjected to several other limitations. Firstly, the samples were drawn from only one industry and for one financial year. We had justified our sample selection by the fact that financial companies have significant roles to play in the economies of the GCC countries. Nevertheless, future research may consider a wider range of companies as samples or to extend this study to other emerging markets. Also, using data from various years would provide a more in-depth understanding of the IFR trend and the possibility of providing more robust results. Secondly, results obtained from this study are confined to the disclosure index used. Future research could 
consider extending the index to include the timeliness of the IFR (e.g. latest updates). Thirdly, this study had relied on government and family ownership to proxy for corporate governance mechanisms as they were relevant in the context of the GCC countries. Future research could use other classifications such as managerial ownership, domestic institutional ownership, and foreign institutional ownership. Another valuable approach is to look at the overall corporate governance mechanism by using a composite index of corporate governance especially in the setting where the roles of internal and external corporate governance are equally important. Finally, the analysis of this study was based on a quantitative analysis of financial and IFR data and the views of companies involved were not expedited. Therefore, it may be reasonable to conduct interviews with companies to determine the logic and perception of the managers in dealing with the IFR practices.

\section{References}

Abdelsalam, O.H., Bryant, S.M., \& Street, D.L. (2007). An examination of comprehensiveness of corporate Internet reporting provided by London listed companies. Journal of International Accounting Research, 6(2), 1-33. http://dx.doi.org/10.2308/jiar.2007.6.2.1

Abrahamson, E. (1991). Managerial fads and fashions: The diffusion and rejection of innovations. Academy of Management Review, 16(3), 586-612. http://dx.doi.org/10.5465/amr.1991.4279484

AbuGhazaleh, N.M., Qasim, A., \& Roberts, C. (2012). The determinants of webbased investor relations activities by companies operating in emerging economies: the case of Jordan. Journal of Applied Business Research, 28(2), 209-226. http:/ / dx.doi.org/10.19030/jabr.v28i2.6842

Agboola, A.A., \& Salawu, M.K. (2012). The determinants of internet financial reporting: Empirical evidence from Nigeria. Research Journal of Finance and Accounting, 3(11), 95-106.

Aguilera, R.V., Filatotchev, I., Gospel, H., \& Jackson, G. (2008). An organizational approach to comparative corporate governance: Costs, contingencies, and complementarities. Organization Science, 19(3), 475-492. http://dx.doi. org/10.1287/orsc. 1070.0322

Aguinis, H., \& Gottfredson, R.K. (2010). Best-practice recommendations for estimating interaction effects using moderated multiple regression. Journal of Organizational Behavior, 31(6), 776-786. http://dx.doi.org/10.1002/ job.686

Ahmed H.A., Bruce M.B., \& Theresa M.D. (2017). The determinants of corporate internet reporting in Egypt: An exploratory analysis, Journal of Accounting in Emerging Economies, 7(1), 35-60. http://dx.doi.org/10.1108/jaee-04-20150024 
Alali, F., \& Romero, S. (2012). The use of the Internet for corporate reporting in the Mercosur (Southern common market): The Argentina case. Advances in Accounting, 28(1), 157-167. http:/ / dx.doi.org/10.1016/j.adiac.2012.03.009

Alanezi, F.S. (2009). Factors influencing Kuwaiti companies' Internet financial reporting. Journal of Economic and Administrative Sciences, 25(2), 44-78. http:/ / dx.doi.org/10.1108/10264116200900007

Al-Hassan, A., Oulidi, N., \& Khamis, M. (2010). The GCC banking sector: Topography and analysis (IMF Working Papers, WP/10/87). Washington, DC: International Monetary Fund.

Al-Htaybat, K. (2011). Corporate online reporting in 2010: A case study in Jordan. Journal of Financial Reporting and Accounting, 9(1), 5-26. http:// dx.doi.org/10.1108/19852511111139778

Ali, A., Chen, T.Y., \& Radhakrishnan, S. (2007). Corporate disclosures by family firms. Journal of Accounting and Economics, 44(1-2), 238-286. http://dx.doi. org/10.1016/j.jacceco.2007.01.006

Ali-Khan, M.N.A., \& Ismail, N.A. (2011). The level of Internet financial reporting of Malaysian companies. Asian Journal of Accounting and Governance, 2, 2739. http:/ / dx.doi.org/10.17576/ajag-2011-2-6539

Ali-Khan, M.N.A., Ismail, N.A., \& Zakuan, N. (2013). Benefits of internet financial reporting in a developing country: Evidence from Malaysia. African Journal of Business Management, 7(9), 719-726.

Al-Khouri, R. (2012). Government ownership, competition, and the risk-taking attitude of the GCC banking system. Advances in Financial Economics, 15, 173-193. http://dx.doi.org/10.1108/s1569-3732(2012)0000015009

Al-Malkawi, H.A.N., Pillai, R., \& Bhatti, M.I. (2014). Corporate governance practices in emerging markets: The case of GCC countries. Economic Modelling, 38, 133-141. http://dx.doi.org/10.1016/j.econmod.2013.12.019

Al-Musalli, M.A.K., \& Ku Ismail K.N.I. (2012). Corporate governance, bank specific characteristics, banking industry characteristics, and intellectual capital (IC) performance of banks in Arab Gulf Cooperation Council (GCC) countries. Asian Academy of Management Journal of Accounting and Finance, $8(1), 115-135$.

Al-Obaidan, A.M. (2008). Optimal bank size: The case of the Gulf Cooperation Council countries. European Journal of Economics, Finance and Administrative Sciences, 11(11), 31-43.

Alqudsi-ghabra, T.M., Al-Bannai, T., \& Al-Bahrani, M. (2011). The Internet in the Arab Gulf Cooperation Council (AGCC): Vehicle of change. International Journal of Internet Science, 6(1), 44-67.

Al-Shammari, B. (2007). Determinants of Internet financial reporting by listed companies on the Kuwait stock exchange. Journal of International Business and Economics, 7(1), 162-178.

Al-Shammari, B. (2013). An investigation of voluntary disclosure by Kuwaiti Shariah-compliant companies. Journal of Economic and Administrative Sciences, 29(1), 21-41. http:/ / dx.doi.org/10.1108/10264111311319213 
Al-Shammari, B., Brown, P., \& Tarca, A. (2008). An investigation of compliance with International accounting standards by listed companies in the Gulf Co-Operation Council member states. The International Journal of Accounting, 43(4), 425-447. http:/ / dx.doi.org/10.1016/j.intacc.2008.09.003

Álvarez, I.G., Sánchez, I.M.G., \& Domínguez, L.R. (2008). Voluntary and compulsory information disclosed online: The effect of industry concentration and other explanatory factors. Online Information Review, 32(5), 596-622. http:/ / dx.doi.org/10.1108/14684520810913990

Aly, D., Simon, J., \& Hussainey, K. (2010). Determinants of corporate Internet reporting: evidence from Egypt. Managerial Auditing Journal, 25(2), 182-202. http:/ / dx.doi.org/10.1108/02686901011008972

Amico, A., Jafar, B., Singhvi, T., Smallman, K., Abdelkhader, G., \& Dunlop. I. (2016). Corporate Governance for Competitiveness in the Middle East and North Africa (Report for the World Economic Forum's MENA Regional Business Council). North Africa: Crescent Enterprises Limited.

Andrikopoulos, A., Merika, A.A., Triantafyllou, A., \& Merikas, A.G. (2013). Internet disclosure and corporate performance: A case study of the international shipping industry. Transportation Research Part A: Policy and Practice, 47, 141-152. http://dx.doi.org/10.1016/j.tra.2012.10.016

Ariff, A.M., Cahan, S., \& Emanuel, D. (2014). Institutional environment, ownership, and disclosure of intangibles: Evidence from East Asia. Journal of International Accounting Research, 13(1), 33-59. http://dx.doi.org/10.2308/ jiar-50655

Arussi, A.S., Selamat, M.H., \& Hanefah, M.M. (2009). Determinants of financial and environmental disclosures through the Internet by Malaysian companies. Asian Review of Accounting, 17(1), 59-76. http://dx.doi. org/10.1108/13217340910956513

Ashbaugh, H., Johnstone, K.M., \& Warfield, T.D. (1999). Corporate reporting on the Internet. Accounting Horizons, 13(3), 241-257. http://dx.doi.org/ 10.2308/acch.1999.13.3.241

Ball, R. (2006). International Financial Reporting Standards (IFRS): Pros and cons for investors. Accounting and Business Research, 36(sup1), 5-27.

Bartulović, M., \& Pervan, I. (2012). Comparative analysis of voluntary internet financial reporting for selected CEE countries. Recent Researches in Applied Economics and Management, 1(1), 296-301.

Basuony, M.A., \& Mohamed, E.K.A. (2014). Determinants of Internet financial disclosure in GCC countries. Asian Journal of Finance and Accounting, 6(1), 70-89. http:/ / dx.doi.org/10.5296/ajfa.v6i1.5085

Baydoun, N., Maguire, W., Ryan, N., \& Willett, R. (2013). Corporate governance in five Arabian Gulf countries. Managerial Auditing Journal, 28(1), 7-22. http:/ / dx.doi.org/10.1108/02686901311282470

Beattie, V., \& Pratt, K. (2003). Issues concerning web-based business reporting: An analysis of the views of interested parties. The British Accounting Review, 35(2), 155-187. http:/ / dx.doi.org/10.1016/s0890-8389(03)00016-7 
Bollen, L., Hassink, H., \& Bozic, G. (2006). Measuring and explaining the quality of Internet investor relations activities: A multinational empirical analysis. International Journal of Accounting Information Systems, 7(4), 273-298. http:// dx.doi.org/10.1016/j.accinf.2006.04.005

Bonsón, E., \& Escobar, T. (2006). Digital reporting in Eastern Europe: An empirical study. International Journal of Accounting Information Systems, 7(4), 299-318. http://dx.doi.org/10.1016/j.accinf.2006.09.001

Bonsón-Ponte, E., Escobar-Rodriguez, T., \& Flores-Munoz, F. (2008). Navigation quality as a key value for the webpage of a financial entity. Online Information Review, 32(5), 623-634. http://dx.doi.org/10.1108/ 14684520810914007

Botosan, C.A., \& Plumlee, M.A. (2002). A re-examination of disclosure level and the expected cost of equity capital. Journal of Accounting Research, 40(1), 2140. http:/ / dx.doi.org/10.1111/1475-679X.00037

Botti, L., Boubaker, S., Hamrouni, A., \& Solonandrasana, B. (2014). Corporate governance efficiency and internet financial reporting quality. Review of Accounting and Finance, 13(1), 43-64. http://dx.doi.org/10.1108/raf-112012-0117

Bowrin, A.R. (2015). Comprehensiveness of Internet reporting by Caribbean companies. Journal of Accounting in Emerging Economies, 5(1), 2-34. http:// dx.doi.org/10.1108/jaee-08-2011-0028

Bushman, R.M., \& Piotroski, J.D. (2006). Financial reporting incentives for conservative accounting: The influence of legal and political institutions. Journal of Accounting and Economics, 42(1-2), 107-148. http://dx.doi.org/ 10.1016/j.jacceco.2005.10.005

Bussin, M. (2012). The Remuneration handbook for Africa. Radburg: Knowres Publishing.

Callen, T., Cherif, R., Hasanov, F., Hegazy, A., \& Khandelwal, P. (2014). Economic diversification in the GCC: Past, present, and future (IMF Discussion Note). Dubai: Inter-national Monetary Fund.

Carcello, J.V., Hermanson, D.R., \& Ye, Z. (2011). Corporate governance research in accounting and auditing: Insights, practice implications, and future research directions. Auditing: A Journal of Practice and Theory, 30(3), 1-31. http://dx.doi.org/10.2308/ajpt-10112

Chahine, S. (2007). Activity-based diversification, corporate governance, and the market valuation of commercial banks in the Gulf Commercial Council. Journal of Management and Governance, 11(4), 353-382. http://dx.doi.org/ 10.1007 /s10997-007-9034-5

Chau, G.K., \& Gray, S.J. (2002). Ownership structure and corporate voluntary disclosure in Hong Kong and Singapore. The International Journal of Accounting, 37(2), 247-265. http://dx.doi.org/10.1016/S0020-7063(02)00153-X

Chau, G.K., \& Gray, S.J. (2010). Family ownership, board independence and voluntary disclosure: evidence from Hong Kong. Journal of International 
Accounting, Auditing and Taxation, 19(2), 93-109. http://dx.doi.org/ 10.1016/j.intaccaudtax.2010.07.002

Chircu, A.M., \& Kauffman, R.J. (2000). Limits to value in electronic commercerelated IT investments. Journal of Management Information Systems, 17(2), 59-80. http://dx.doi.org/10.1080/07421222.2000.11045645

Cooke, T.E, \& Wallace, R.S.O. (1990). Financial disclosure regulation and its environment: A review and further analysis. Journal of Accounting and Public Policy, 9, 79-110. http:/ / dx.doi.org/10.1016/0278-4254(90)90013-p

Cormier, D., Ledoux, M.J., \& Magnan, M. (2012). The moderation effect of voluntary disclosure on the relation between earnings quality and information asymmetry: Some Canadian evidence. International Journal of Accounting, Auditing and Performance Evaluation, 8(2), 157-183. http:// dx.doi.org/10.1504/ijaape.2012.046706

Craven, B.M., \& Marston, C.L. (1999). Financial reporting on the Internet by leading UK companies. The European Accounting Review, 8(2), 321-333. http://dx.doi.org/10.1080/096381899336069

Debreceny, R., Gray, G.L., \& Rahman, A. (2002). The determinants of Internet financial reporting. Journal of Accounting and Public Policy, 21(4-5), 371-394. http:/ /dx.doi.org/10.1016/S0278-4254(02)00067-4

Desoky, A.M. (2009). Company characteristics as determinants of Internet financial reporting in emerging markets: The case of Egypt. Research in Accounting in Emerging Economies, 9, 31-71. http://dx.doi.org/10.1108/ s1479-3563(2009)0000009004

Dutta, P., \& Bose, S. (2007). Web-based corporate reporting in Bangladesh: An exploratory study. The Cost and Management, 35(6), $29-45$.

Elmasry, T., Benni, E., Patel, J., \& Moore, J.P. (October, 2016). Digital Middle East: Transforming the region into a leading digital economy. Retrieved from https://www.mckinsey.com/global-themes/ middle-east-and-africa

Elsayed, A.N.E., El-Masry, A.A., \& Elbeltagi, I.M. (2010). Corporate governance, firm characteristics and Internet financial reporting: Evidence from Egyptian listed companies. Corporate Ownership and Control, 7(4), 396-426. http://dx.doi.org/10.22495/cocv7i4c4p1

Eng, L.L., \& Mak, Y.T. (2003). Corporate governance and voluntary disclosure. Journal of Accounting and Public Policy, 22(4), 325-345. http://dx.doi. org/10.1016/s0278-4254(03)00037-1

Evans, J., Henderson, D., \& Trinkle, B. (2011). The link between Internet financial reporting and information asymmetry for American depository receipts. Journal of Modern Accounting and Auditing, 7(9), 947-965.

Fan, J., \& Wong, T.J. (2002). Corporate ownership structure and the informativeness of accounting earnings in East Asia. Journal of Accounting and Economics, 33(3), 401-425. http://dx.doi.org/10.1016/S0165-4101(02)00047-2

Fleming, G., Heaney, R., \& McCosker, R. (2005). Agency costs and ownership structure in Australia. Pacific-Basin Finance Journal, 13(1), 29-52. http:// dx.doi.org/10.1016/j.pacfin.2004.04.001 
Francis, J., Khurana, I., \& Pereira, R. (2005). Disclosure incentives and effects on cost of capital around the world. The Accounting Review, 80(4), 1125-1162. http://dx.doi.org/10.2308/accr.2005.80.4.1125

Gheeraert, L. (2014). Does Islamic finance spur banking sector development? Journal of Economic Behavior and Organization, 103, 4-20. http://dx.doi. org/10.1016/j.jebo.2014.02.013

Ghnaya, B.B. (2015). Research and development disclosure information on internet by multinational corporations. International Journal of Information Technology and Management, 14(4), 274-304. http://dx.doi.org/10.1504/ ijitm.2015.072080

Hair, J.F., Black, W.C., Babin, B.J., \& Anderson, R.E.. (2010). Multivariate data analysis (7th edition). Upper Saddle River, NJ: Prentice Hall.

Halawi, A., \& Awan, H. (2008). TNI market insight. Retrieved from hawkamah. org/uploads/reports/BASIC_FinalAug08.pdf.

Haniffa, R., \& Hudaib, M. (2006). Corporate governance structure and performance of Malaysian listed companies. Journal of Business Finance and Accounting, 33(7-8), 1034-1062. http://dx.doi.org/10.1111/j.14685957.2006.00594.x

Healy, P.M., \& Palepu, K.G. (2001). Information asymmetry, corporate disclosure, and the capital markets: A review of the empirical disclosure literature. Journal of Accounting and Economics, 31(1-3), 405-440. http:// dx.doi.org/10.1016/S0165-4101(01)00018-0

Ho, S.M., \& Wong, K. (2001). A study of the relationship between corporate governance structures and the extent of voluntary disclosure. Journal of International Accounting, Auditing and Taxation, 10(2), 139-156. http:// dx.doi.org/10.1016/S1061-9518(01)00041-6

Isidro H., \& Raonic, I. (2012). Firm incentives, institutional complexity and the quality of "harmonized" accounting numbers. International Journal of Accounting, 47(4), 407-436. http:/ / dx.doi.org/10.1016/j.intacc.2012.10.007

Jo, S., \& Jung, J. (2005). A cross-cultural study of the world wide web and public relations. Corporate Communications: An International Journal, 10(1), 24-40.

Jones, M.J., \& Xiao, J.Z. (2004). Financial reporting on the Internet by 2010: A consensus view. Accounting Forum, 28(3), 237-263. http://dx.doi. org/10.1016/j.accfor.2004.07.002

Kamla, R., \& Roberts, C. (2010). The global and the local: Arabian Gulf States and imagery in annual reports. Accounting, Auditing and Accountability Journal, 23(4), 449-481. http://dx.doi.org/10.1108/09513571011041589

Kelton, A.S., \& Yang, Y. (2008). The impact of corporate governance on Internet financial reporting. Journal of Accounting and Public Policy, 27(1), 62-87. http://dx.doi.org/10.1016/j.jaccpubpol.2007.11.001

Khediri, K.B., Charfeddine, L., \& Youssef, S.B. (2014). Islamic versus conventional banks in the GCC countries: A comparative study using classification techniques. Research in International Business and Finance, 33, 75-98. http:// dx.doi.org/10.1016/j.ribaf.2014.07.002 
KPMG. (2017). GCC listed banks results: Navigating through change on year ended 31 December 2016. Retrieved from https://assets.kpmg.com/content/dam/ kpmg/ae/pdf/gcc-listed-banks-report.pdf

Leuz, C., \& Verrecchia, R.E. (2000). The economic consequences increased disclosure. Journal of Accounting Research, 38, 91-124. http://dx.doi. org/10.2307/2672910

Leuz, C., Nanda, D., \& Wysocki, P.D. (2003). Earnings management and investor protection: An international comparison. Journal of Financial Economics, 69(3), 505-527. http:/ / dx.doi.org/10.1016/S0304-405X(03)00121-1

Lybaert, N. (2002). On-line financial reporting: An analysis of the Dutch listed companies. The International Journal of Digital Accounting Research, 2(4), 195234. http://dx.doi.org/10.4192/1577-8517-v2_7

Maghyereh, A.I., \& Awartani, B. (2012). Financial integration of GCC banking markets: A non-parametric bootstrap DEA estimation approach. Research in International Business and Finance, 26(2), 181-195. http://dx.doi. org/10.1016/j.ribaf.2011.10.001

Maghyereh, A.I., \& Awartani, B. (2014). Bank distress prediction: Empirical evidence from the Gulf Cooperation Council countries. Research in International Business and Finance, 30, 126-147. http://dx.doi.org/10.1016/j.ribaf.2013.07.001

Mohamed, E., \& Basuony, M.A.K. (2014). Determinants and characteristics of voluntary Internet disclosures in GCC countries. The International Journal of Digital Accounting Research, 14, 57-91. http://dx.doi.org/10.4192/15778517-v14_3

Mokhtar, E.S. (2017). Internet financial reporting determinants: A meta-analytic review. Journal of Financial Reporting and Accounting, 15(1), 116-154.

Momany, M.T., \& Pillai, R. (2013). Internet financial reporting in UAE - analysis and implications. Global Review of Accounting and Finance, 4(2), 142-160.

Moradi, M., Salehi, M., \& Arianpoor, A. (2011). A study of the reasons for shortcomings in establishment of Internet financial reporting in Iran. African Journal of Business Management, 5(8), 3312-3321. http://dx.doi. org/10.5897/ AJBM10.1451

Ojah, K., \& Mokoaleli-Mokoteli, T. (2012). Internet financial reporting, infrastructures and corporate governance: An international analysis. Review of Development Finance, 2(2), 69-83. http://dxdoi.org/10.1016/j.rdf.2012. 04.001

Orens, R., Aerts, W., \& Cormier, D. (2010). Web-based non-financial disclosure and cost of finance. Journal of Business Finance and Accounting, 37(9-10), 1057-1093. http:/ /dx.doi.org/10.1111/j.1468-5957.2010.02212.x

Oyelere, P., \& Kuruppu, N. (2012). Voluntary Internet financial reporting practices of listed companies in the United Arab Emirates. Journal of Applied Accounting Research, 13(3), 298-315. http://dx.doi.org/10.1108/ 09675421211281353 
Pérez, C.C., Bolívar, M.P.R., \& Hernández, A.M.L. (2008). E-Government process and incentives for online public financial information. Online Information Review, 32(3), 379-400. http:/ / dx.doi.org/10.1108/14684520810889682

Pervan, I. (2006). Voluntary financial reporting on the Internet - analysis of the practice of Croatian and Slovene listed joint stock companies. Financial Theory and Practice, 30(1), 1-27.

Pollalis, Y.A. (2003). Patterns of co-alignment in information-intensive organizations: Business performance through integration strategies. International Journal of Information Management, 23(6), 469-492. http://dx.doi.org/ 10.1016/S0268-4012(03)00063-X

Puspitaningrum, D., \& Atmini, S. (2012). Corporate governance mechanism and the level of Internet financial reporting: Evidence from Indonesian companies. Procedia Economics and Finance, 2, 157-166. http://dx.doi. org/10.1016/s2212-5671(12)00075-5

Qasim, A., \& Al Barghouthi, S. (2017). Corporate Internet financial reporting practices of companies operating in emerging economies: An empirical investigation on listed companies in the United Arab Emirates. International Journal of Business and Society, 18(3), 641-649.

Safieddine, A. (2009). Islamic financial institutions and corporate governance: New insights for agency theory. Corporate Governance: An International Review, 17(2), 142-158. http:/ / dx.doi.org/10.1111/j.1467-8683.2009.00729.x

Samaha, K., \& Dahawy, K. (2010). Factors influencing corporate disclosure transparency in the active share trading companies: An explanatory study. Research in Accounting in Emerging Economies, 10, 87-118. http://dx.doi. org/10.1108/s1479-3563(2010)0000010009

Samargandi, N., Fidrmuc, J., \& Ghosh, S. (2014). Financial development and economic growth in an oil-rich economy: The case of Saudi Arabia. Economic Modelling, 43, 267-278. http://dx.doi.org/10.1016/j.econmod. 2014.07.042

Santos, A. (2015). Integrated ownership and control in the GCC corporate sector (IMF Working Paper). Washington, DC: International Monetary Fund.

Saudagaran, S.M., \& Diga, J.G. (1997). Accounting regulation in ASEAN: A choice between the global and regional paradigms of harmonization. Journal of International Financial Management \& Accounting, 8(1), 1-32.

Thangatorai, R., Jaffar, R., \& Shukor, Z.A. (2013). The effect of corporate governance mechanism on the voluntary Internet financial reporting: A case of Malaysia. Recent Advances in Management, Marketing and Finances, 1, 81-86.

Trabelsi, S., Labelle, R., \& Dumontier, P. (2008). Incremental voluntary disclosure on corporate websites, determinants and consequences. Journal of Contemporary Accounting and Economics, 4(2), 120-155. http://dx.doi. org/10.1016/s1815-5669(10)70032-1

Turmin, S.Z., Hamid, F.A., \& Ghazali, N.A.M. (2015). Corporate Internet reporting in emerging economic countries: The Malaysian perspective. Pertanika Journal of Social Sciences and Humanities, 23, 73-88. 
Turrent, C.B., \& Ariza, L.R. (2012). Corporate information transparency on the Internet by listed companies in Spain (IBEX35) and Mexico (IPYC). The International Journal of Digital Accounting Research, 12, 1-37. http://dx.doi. org/10.4192/1577-8517-v12_1

United Nations. (2017). The world investment report. Geneva: United Nations Publications. Retrieved from http://unctad.org/en/PublicationsLibrary/ wir2017_en.pdf.

Wang, D. (2006). Founding family ownership and earnings quality. Journal of Accounting Research, 44(3), 619-656. http://dx.doi.org/10.1111/j.1475-679x. 2006.00213.x

Wang, J. (2003). Governance role of different types of state-shareholders: Evidence from China's listed companies (Doctoral thesis, Hong Kong University of Science and Technology). Retrieved from http://ihome.ust.hk/ wangjw/ download/stateshares.pdf

Wang, Z., Ali, M.J., \& Al-Akra, M. (2013). Value relevance of voluntary disclosure and the global financial crisis: Evidence from China. Managerial Auditing Journal, 28(5), 444-468. http:/ / dx.doi.org/10.1108/02686901311327218

Wan-Hussin, W.N. (2009). The impact of family-firm structure and board composition on corporate transparency: Evidence based on segment disclosures in Malaysia. The International Journal of Accounting, 44(4), 313333. http:/ /dx.doi.org/10.1016/j.intacc.2009.09.003

Ward, A.J., Brown, J.A., \& Rodriguez, D. (2009). Governance bundles, firm performance, and the substitutability and complementarity of governance mechanisms. Corporate Governance: An International Review, 17(5), 646-660. http://dx.doi.org/10.1111/j.1467-8683.2009.00766.x

Webb, K., Cahan, S., \& Sun, J. (2008). The effect of globalization and legal environment on voluntary disclosure. The International Journal of Accounting, 43(3), 219-245. http:/ / dx.doi.org/10.1016/j.intacc.2008.06.001

World Bank (2018). World development indicators 2018. Washington DC: Author.

Xiao, J.Z., Yang, H., \& Chow, C.W. (2004). The determinants and characteristics of voluntary Internet-based disclosures by listed Chinese companies. Journal of Accounting and Public Policy, 23(3), 191-225. http://dx.doi. org/10.1016/j.jaccpubpol.2004.04.002

Yusof, R.M., \& Bahlous, M. (2013). Islamic banking and economic growth in GCC and East Asia countries: A panel cointegration analysis. Journal of Islamic Accounting and Business Research, 4(2), 151-172. http://dx.doi. org/10.1108/jiabr-07-2012-0044 
Corporate Ownership, Internet Penetration and Internet Financial Reporting

\section{Appendices}

Appendix A: Research Framework

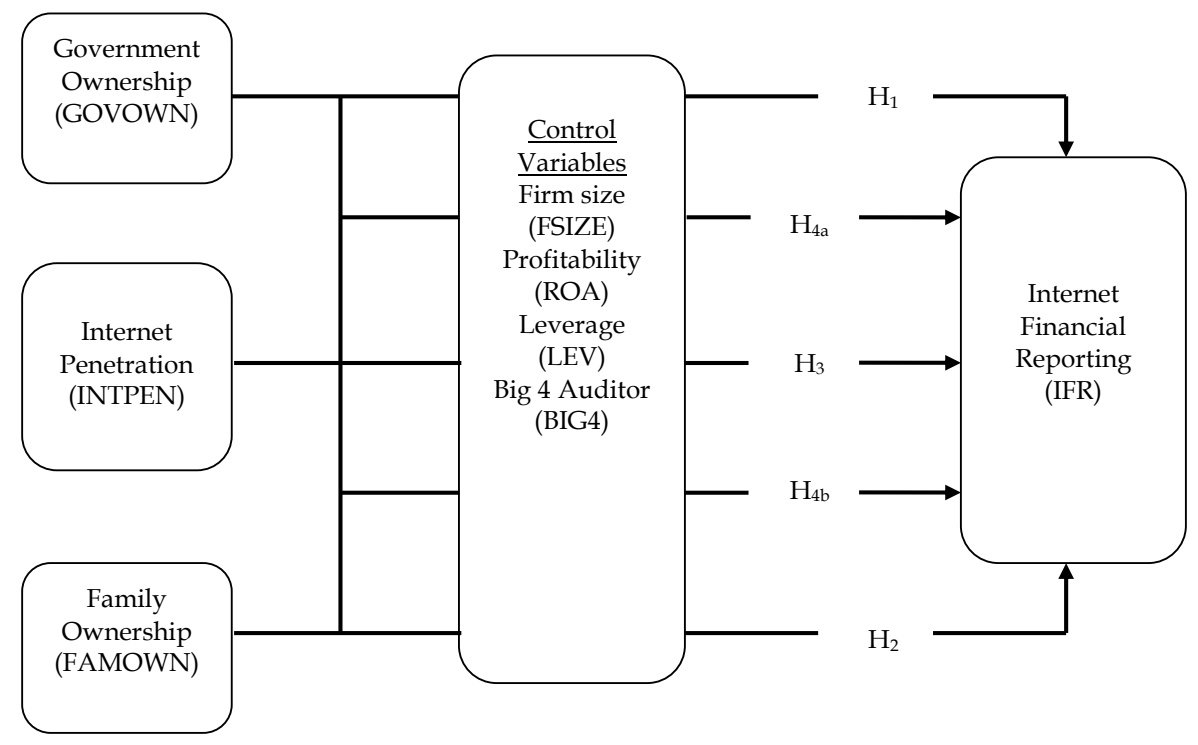


Akmalia M. Ariff, Hasan O. Bin-Ghanem, and Hafiza Aishah Hashim

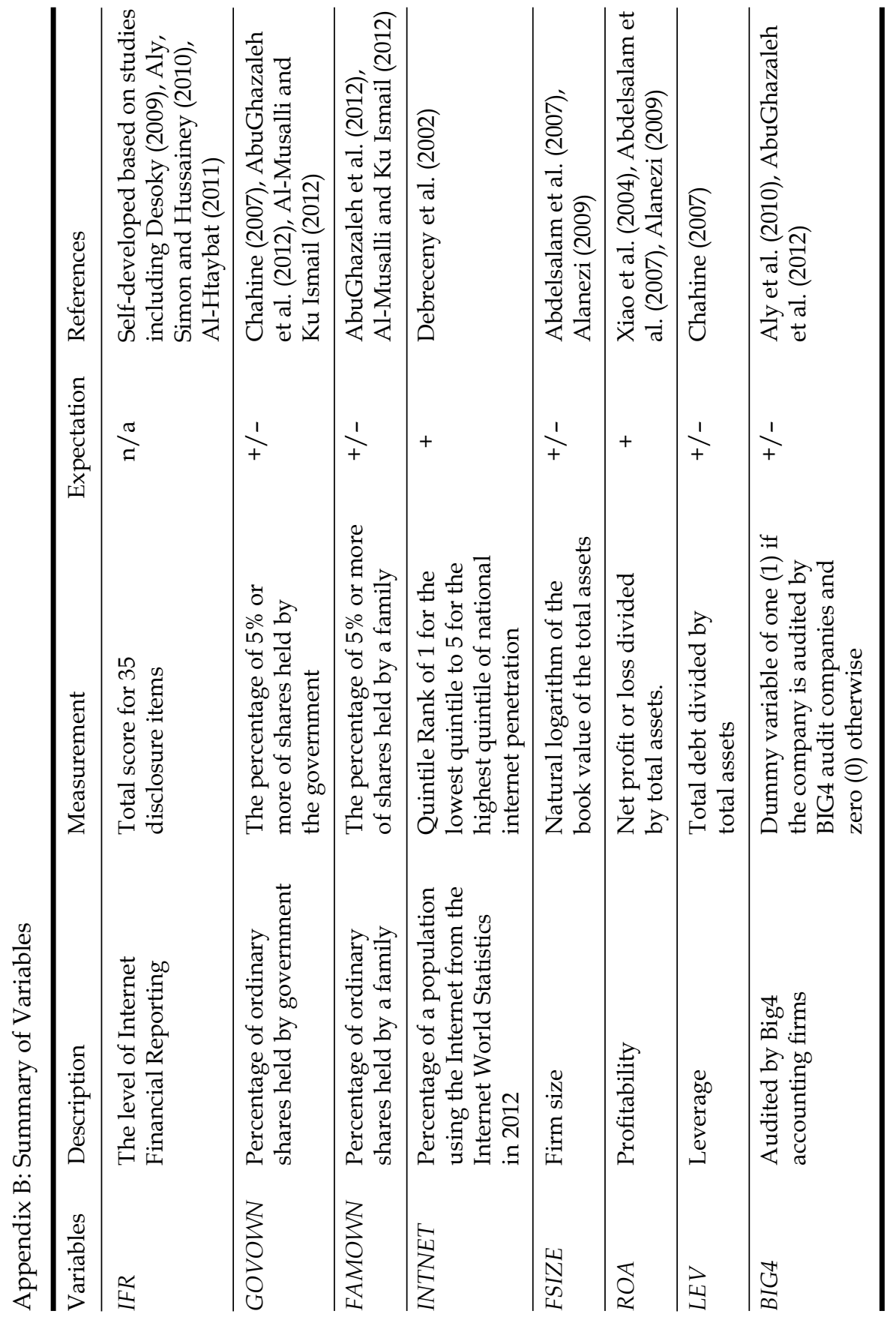


Appendix C: Extent of Individual Items of IFR Index

Items included

No. of Companies Percentage

Presentation items

Website available Arabic

Website available English

152

100

Connect with us on $\backslash$ follow us: $F \backslash T^{*}$

42

28

Latest News

122

80

Pull-down menu

115

76

Contact us

149

98

Link to the stock exchange website

Link to parent or subsidiary

Frequently asked question (FAQ)

56

37

Phone No for investor relations

E-mail address for investor relations

Postal address

Search box (Internal search engines)

Annual report in PDF format

134

Annual report in HTML format

Sitemap

90

Content items

Current year annual report

Past years annual report

Half year annual report

Quarterly reports

Balance sheet

Income statement

Statement of shareholders' equity

Cash flow

Current share prices

Historical share prices

Financial highlight/summary

Notes to financial statements

Background of the organization

Description of the nature of the company

Names of board members

The board of directors information

Auditor's report

Note: ${ }^{*} \mathrm{~F}=$ Facebook and $\mathrm{T}=$ Twitter. 
